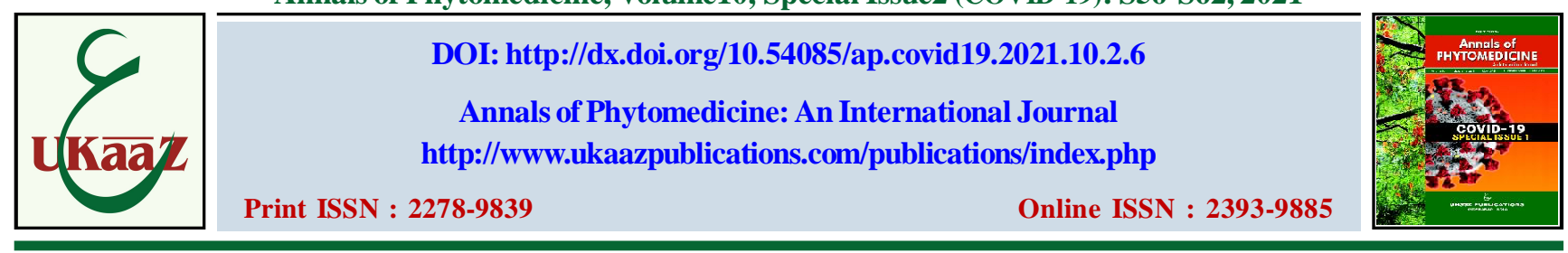

\title{
Consumer's attitude and awareness towards functional foods during COVID-19
}

\author{
Rizwana, Eram S. Rao, Anita Sondhi*, Aparna Agarwal**, Anishka Verma, Krishan Kant and Deepak Kumar \\ Department of Food Technology, Bhaskaracharya College of Applied Sciences, University of Delhi, Dwarka, New Delhi-110075, India \\ *Department of Biochemistry, Bhaskaracharya College of Applied Sciences, University of Delhi, Dwarka, New Delhi-110075, India \\ **Department of Food and Nutrition and Food Technology, Lady Irwin College, University of Delhi, New Delhi-110001, India
}

\section{Article Info}

Article history

Received 11 July 2021

Revised 28 August 2021

Accepted 29 August 2021

Published Online 30 December 2021

\section{Keywords}

Bioactive compounds

Diseases

Functional foods

Health Benefits

Medicinal

\begin{abstract}
COVID-19 is an infectious disease which was originated in Wuhan (China) and is declared a pandemic by the World Health Organization. Functional foods are gaining popularity as they have been boosting immunity and capable to fight against various diseases including the COVID-19. Functional foods are categorized under the type of food products that possess physiological benefits. These foods are essential for health and help in improving one's health by preventing and curing several chronic diseases. This study has been conducted to evaluate the consumer's awareness and their knowledge of functional foods and their health benefits. A survey method was employed using a set of questions to assess consumer's knowledge and awareness. The scientific goal of this study was to increase awareness in the population about the advantages of these foods. The survey was conducted online on sample size of 301 participants for functional foods and, the data thus obtained was magnificent. The majority of the participants were either students or working professionals. More than half of the participants knew functional foods and were regular consumers. This survey gave an idea about what people think of the new emerging foods, their health claims, and their consumption during COVID-19, therefore, moving towards a healthy future.
\end{abstract}

\section{Introduction}

COVID-19 (Coronavirus Disease-2019) is an infectious disease that was first identified in Wuhan in China and affected 196 countries and territories. This disease is caused by SARS-CoV-2, i.e., severe acute respiratory syndrome coronavirus 2 . World Health Organization (WHO) on 11 March 2020, declared COVID-19 disease as a pandemic, and till 24 July 2020 , about $15,296,926$ cases and 628,903 deaths have occurred (Ben Hassen et al., 2020). The emergence of this pandemic ultimately affects the health and immune system of the consumers. Thus, in this situation, healthy food is a vital requirement to fight against this pandemic and the consumption of functional foods needs to boost the immunity of consumers to suppress this infectious disease.

Food plays a vital role in the overall development of a human being by fulfilling the nutritional requirement of a living being such as protein, fats, carbohydrates, vitamins, and minerals. With the advancement in scientific research, it has been claimed that food also possesses beneficial and medicinal bioactive compounds that provide health benefits beyond basic nutrition, termed as functional foods (Kumar et al., 2017). World Health Organization also claimed the relationship of dietary problems with chronic diseases and quality of life. Thus, functional foods are a key necessity for

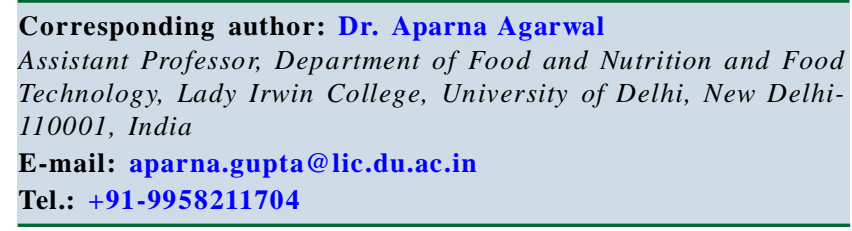

Copyright () 2021 Ukaaz Publications. All rights reserved.

Email: ukaaz@yahoo.com; Website: www.ukaazpublications.com improving health by preventing various chronic diseases (KusterBoluda et al., 2017; World Health Organization, 2000).

Japan first emerged the concept of functional food in 1984 under the legislative food category, termed as FOSHU. To be classified functional foods under FOSHU, they must satisfy the three basic requirements including safety, effectiveness, and presence of bioactive compounds in them (Martirosyan et al., 2015). Different countries are involved in the production of functional foods such as Japan and the United States. Around $60 \%$ of the global functional food market of the United States and Japan is occupied with beverages and around $20 \%$ of the functional food market in the United States is equipped with cereal products whereas $15 \%$ of the functional food market in Japan is occupied with confectionary products (Jedrusek-Golinska et al., 2020).

A lot of factors are responsible for the consumer willingness of purchasing functional foods which include their taste, cost, quality, convenience, and essential medicinal health benefits. Research and business should be combined and analyzed in the production of more healthy functional foods when compared to conventional food products (Urala et al., 2007). There are always different segments of consumers when purchasing or consuming functional foods. The first segment can be termed as functional food lovers. This segment usually has higher trust over functional foods due to their health-conscious mentality. They are more concerned about consuming healthy food so more willing to consume functional foods. The second segment can be termed as indifferent to functional foods in which consumers depend on healthy food but they are not much convinced about the health benefits of functional foods. In 
such cases, awareness should be increased by promoting the positive health characteristics of functional foods. The third and last category is termed as suspicious about functional foods. This segment involves a higher proportion of males than females and they concern about their diet but do not consider the functional foods to be healthy or tastier to eat (Marina et al., 2014). The functional food market is one of the most widely known in the world which also helps in preventing various diseases such as cardiovascular diseases, type-2 diabetes, and cancer (Jedrusek-Golinska et al., 2020). These foods are categorized into various market segments including fruits and vegetables, cereals, dairy, tea, flaxseeds, seafood, vitamins, egg, herbs, and meat as illustrated in Table 1 (Kaur et al., 2011).

Table 1: Market segments of functional foods and their benefits (Kaur et al., 2011)

\begin{tabular}{|c|c|c|}
\hline Category of functional foods & Major source & Benefits \\
\hline Fruits and vegetables & $\begin{array}{l}\text { Polyphenols such as anthocyanins, flavonols, } \\
\text { resveratrol }\end{array}$ & $\begin{array}{l}\text { Prevent cancer, cardiovascular diseases, } \\
\text { diabetes }\end{array}$ \\
\hline Cereals & Insoluble dietary fiber, water-soluble fiber & Lowering cholesterol, act as prebiotics \\
\hline Dairy & Bioactive peptides in milk & $\begin{array}{l}\text { Lowers blood pressure, preventing } \\
\text { cardiovascular diseases }\end{array}$ \\
\hline Tea & Catechins (Polyphenols) & $\begin{array}{l}\text { Anticancer, antioxidant, antiviral, } \\
\text { antibacterial activities }\end{array}$ \\
\hline Flaxseeds & $\alpha$-linolenic acid (ALA) & $\begin{array}{l}\text { Prevent cancer, cardiovascular diseases, } \\
\text { blood pressure, immune disorders }\end{array}$ \\
\hline Seafood & Omega-3 fatty acids, proteins & $\begin{array}{l}\text { Anticancer, antihypertensive, antiviral, } \\
\text { and antioxidant properties }\end{array}$ \\
\hline Vitamins & $\begin{array}{l}\text { Vitamin } \mathrm{B}_{6} \text {, vitamin } \mathrm{B}_{12} \text {, vitamin } \mathrm{C} \text {, and } \\
\text { vitamin } \mathrm{K}\end{array}$ & $\begin{array}{l}\text { Preventing cardiovascular diseases, } \\
\text { osteoporosis, colorectal carcinoma }\end{array}$ \\
\hline Egg & Omega-3 polyunsaturated fatty acids & $\begin{array}{l}\text { Prevent heart disease, blood pressure, } \\
\text { atherosclerosis }\end{array}$ \\
\hline Herbs & $\begin{array}{l}\text { Curcumin in turmeric, methylhydroxychal- } \\
\text { cone in cinnamon }\end{array}$ & $\begin{array}{l}\text { Prevent bronchitis, asthma, cardiovascular } \\
\text { diseases, Parkinson's diseases, obesity, } \\
\text { AIDS, diabetes }\end{array}$ \\
\hline Meat & $\begin{array}{l}\text { Conjugated linolenic acid (CLA), taurine, } \\
\text { L-carnitine, creatine, antioxidants }\end{array}$ & $\begin{array}{l}\text { Reduce the risk of cardiovascular diseases, } \\
\text { atherosclerosis, and type- } 2 \text { diabetes }\end{array}$ \\
\hline
\end{tabular}

Functional foods can be classified into four different categories involving fortified products, enriched products, altered products, and enhanced commodities. Fortified products are those food products that are fortified with additional nutrients. For example, vitamin $\mathrm{C}$ fortified fruit juice. Enriched products are those in which additional new nutrients are added not normally found in that food; for example, prebiotics and probiotics. Altered products are those food products from which deleterious components are removed and replaced by beneficial components. For example, fibers in the form of fat releasers in meat products. Enhanced commodities are those in which components present in food are naturally enhanced; for example, enhanced/increased omega-3 in eggs (Bigliardi et al., 2013). Ingredients such as vitamins, minerals, dietary fibers, oligosaccharides, antioxidants, lactic acid, omega-3 fatty acids, lignins, and bacteria cultures are responsible for making the foods functional. However, many of such ingredients are found in medicinal plants in India including clove, garlic, turmeric, ginger, cinnamon, fenugreek, and mustard (Lobo et al., 2010). And these ingredients present in different plant foods are beneficial in reducing the COVID-19 infection risk. However, many people who possess chronic diseases and a weaker immune system are more prone to COVID-19 disease. Thus, it is essential to boost the immune system to combat viral infections.

As the concerns about healthy functional foods are increasing at a wider rate, thus there is a need for the development of standards and guidelines for the awareness and health benefits for producers as well as consumers. The standards and guidelines play a vital role as it helps in preventing consumers from misleading and false claims about the product during new product development and its marketing. Today, due to the shift in lifestyle patterns, consumers are now well known to maintain their health to be free from various diseases (Kumar et al., 2017).

The main objectives of this study was to determine consumer's attitude and awareness towards functional foods in the COVID-19 pandemic; to gather consumer's views on functional foods; to identify the factors determining consumer's purchase and consumption of functional foods and; to check consumers understanding of nutrient labeling and health claims of functional foods.

\section{Materials and Methods}

The survey focused on the attitude and the awareness of the consumer towards functional foods and their benefits during the COVID-19 pandemic, their demand and choice for purchasing functional food, and lastly about the health and nutritional benefits.

The survey was conducted among a sample size of 301 people from all age groups and coming from different households (Jain $e t$ al., 2014). Data was collected by the means of an online questionnaire which consisted of a total of 28 questions, collecting the basic information of the consumer as well as the general questions regarding functional foods and their health benefits. Most 
of the questions were multiple choice type and a few were checkbox type.

\section{Questionnaire}

The questionnaire had a set of 28 questions, out of which 6 questions were primarily focussed on getting the knowledge of the consumer and his background. A few general questions were asking about the factors considered by the consumer while purchasing any food product, their observation of the nutritional label present on the product packaging, and their choice likelihood of purchasing functional foods during the COVID-19 period (Vella et al., 2014).

Apart from these were the questions based solely on the purchase of knowledge of functional foods. Those included questions like:

- For the proportion of consumers who said yes to the consumption of functional foods:

- How come you are aware of the use of functional foods?

- What are your reasons for buying functional foods?

- What kind of functional foods do you consume during COVID19 ?

- What are the health claims mentioned on the package and do you believe in them or not?

- For what health benefit would you like to consume functional foods?

- For the proportion of consumers who said no to the consumption of functional foods:

- Reasons and factors leading to the non-purchasing of functional foods?

- Preferences for additional benefits in functional foods?

The remaining questions focused on the health claims and laws related to that, whether the consumer is aware of any law or any regulatory body related to the food products or not, and the consumer's judgment towards the truthfulness of the claims made by these foods.

\section{Results}

The study examined consumer awareness about functional foods, whether they consume them or not during the COVID-19 pandemic period, and their health claims. A total of 301 randomly chosen people took part in the survey (Table 2), out of which $54.2 \%$ were male and $45.8 \%$ were female. The results showed that both the genders were equally interested (since the percentage is nearly the same) in knowing about functional foods. Adults (25-30 years) and teenagers (15-20 years) participated the most in the survey as depicted in Table 2.

The majority of the participants were students, i.e., 53.8\%. Among students, those pursuing high school education were $19.3 \%$, graduation was $42.2 \%$ and post-graduation was $31.6 \%$, followed by working professionals, i.e., $37.9 \%$. $50 \%$ of the participants having an annual family income of 5-10 lakhs or more and around $71.8 \%$ of participants had $2-5$ members in their household while $9.6 \%$ had 2 or less than 2 members and the rest $18.6 \%$ had more than 5 members (Table 2).
Table 2: Demographic characteristics of participants

\begin{tabular}{|c|c|c|c|}
\hline Participants & $\mathrm{N}$ & 301 & \\
\hline \multirow[t]{2}{*}{ Gender } & Male & 163 & $54.2 \%$ \\
\hline & Female & 138 & $45.8 \%$ \\
\hline \multirow[t]{7}{*}{ Age (years) } & $15-20$ & 78 & $25.9 \%$ \\
\hline & $20-25$ & 66 & $21.9 \%$ \\
\hline & $25-30$ & 106 & $35.2 \%$ \\
\hline & $30-35$ & 22 & $7.30 \%$ \\
\hline & $35-40$ & 5 & $1.66 \%$ \\
\hline & $40-45$ & 6 & $1.99 \%$ \\
\hline & $45+$ & 18 & $5.98 \%$ \\
\hline \multirow{5}{*}{$\begin{array}{l}\text { Family income } \\
\text { (Lakh per annum) }\end{array}$} & $<1$ & 52 & $17.27 \%$ \\
\hline & $1-3$ & 47 & $15.61 \%$ \\
\hline & $3-5$ & 57 & $18.93 \%$ \\
\hline & $5-10$ & 75 & $24.91 \%$ \\
\hline & $>10$ & 70 & $23.25 \%$ \\
\hline \multirow[t]{3}{*}{ No. of family members } & $1-2$ & 29 & $9.63 \%$ \\
\hline & $2-5$ & 216 & $71.76 \%$ \\
\hline & $>5$ & 56 & $18.60 \%$ \\
\hline \multirow[t]{4}{*}{ Occupation } & Student & 162 & $53.82 \%$ \\
\hline & Homemaker & 10 & $3.32 \%$ \\
\hline & $\begin{array}{l}\text { Working } \\
\text { professional }\end{array}$ & 114 & $37.87 \%$ \\
\hline & Self employed & 15 & $4.98 \%$ \\
\hline \multirow{4}{*}{$\begin{array}{l}\text { Educational } \\
\text { qualification }\end{array}$} & High school & 58 & $19.26 \%$ \\
\hline & Graduate & 127 & $42.19 \%$ \\
\hline & Post graduate & 95 & $31.56 \%$ \\
\hline & Other & 21 & $6.97 \%$ \\
\hline
\end{tabular}

Table 3: Different views of participants on functional foods

\begin{tabular}{|l|r|r|c|}
\hline Views & Yes & No & $\begin{array}{c}\text { Sometimes } \\
\text { /may be }\end{array}$ \\
\hline $\begin{array}{l}\text { Participants aware of } \\
\text { functional foods }\end{array}$ & $62.8 \%$ & $37.2 \%$ & $0 \%$ \\
\hline $\begin{array}{l}\text { Participants who buy } \\
\text { functional foods }\end{array}$ & $58.8 \%$ & $41.2 \%$ & $0 \%$ \\
\hline $\begin{array}{l}\text { Participants checking the } \\
\text { nutritional label }\end{array}$ & $47.8 \%$ & $13.3 \%$ & $38.9 \%$ \\
\hline $\begin{array}{l}\text { Participants believing in } \\
\text { health claims }\end{array}$ & $35 \%$ & $8.5 \%$ & $56.5 \%$ \\
\hline $\begin{array}{l}\text { Participants satisfied by } \\
\text { health claims }\end{array}$ & $31.6 \%$ & $5.1 \%$ & $63.3 \%$ \\
\hline $\begin{array}{l}\text { Participants opting for health } \\
\text { claims over well-known brand }\end{array}$ & $45.2 \%$ & $9.3 \%$ & $45.5 \%$ \\
\hline $\begin{array}{l}\text { Participants believing in high } \\
\text { price of foods having health } \\
\text { benefits }\end{array}$ & $48.2 \%$ & $6 \%$ & $45.8 \%$ \\
\hline
\end{tabular}


Table 4: Number of participants consuming different types of functional foods

\begin{tabular}{|l|c|}
\hline Type of functional foods & Number of consumers \\
\hline Milk and dairy products (vit. A fortified milk, probiotic dahi, yakult, etc.) & 155 \\
\hline Cereal Products (Fe fortified wheat flour, cereals, muesli, etc.) & 118 \\
\hline Beverages (juices and energy drinks, etc.) & 80 \\
\hline Oils (fortified with micronutrients) & 9 \\
\hline
\end{tabular}

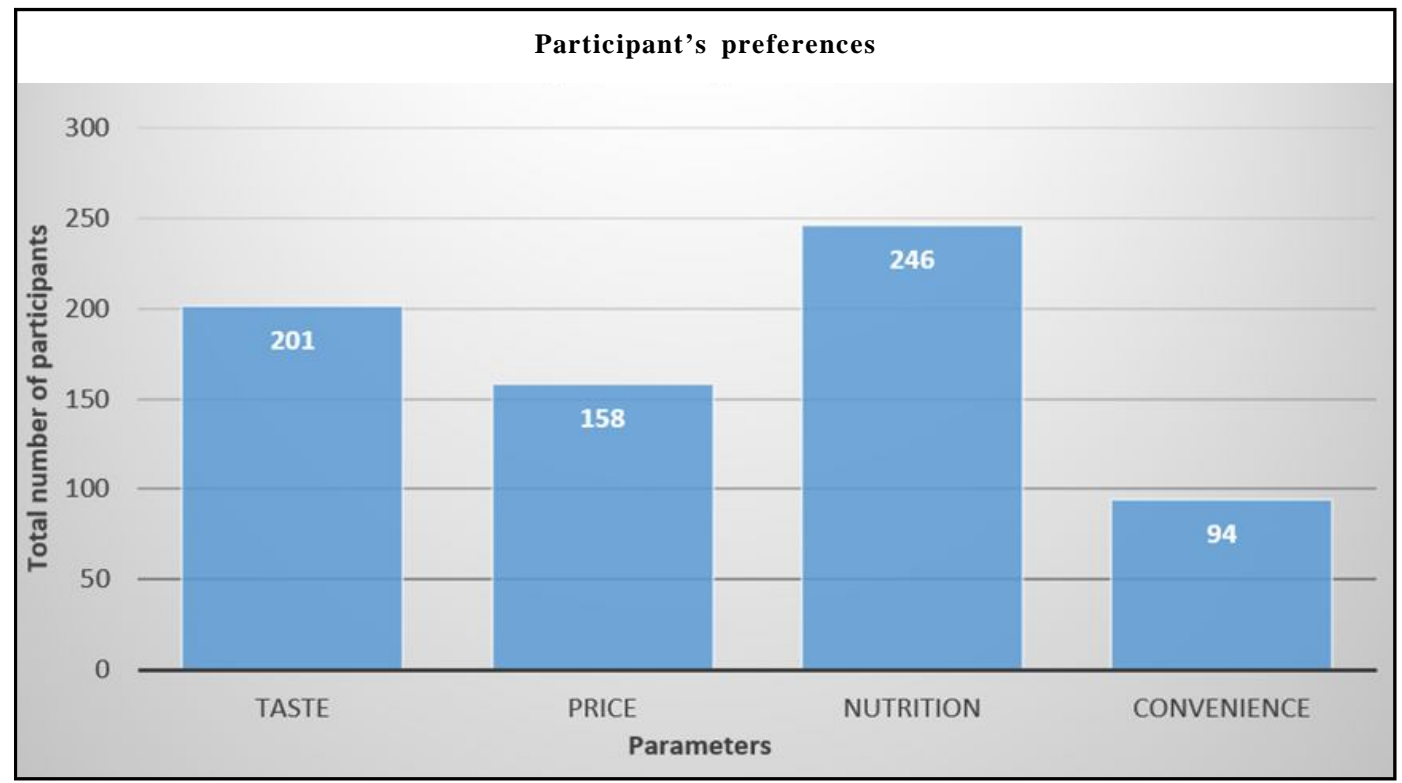

Figure 1: Preference of participants while purchasing functional foods.

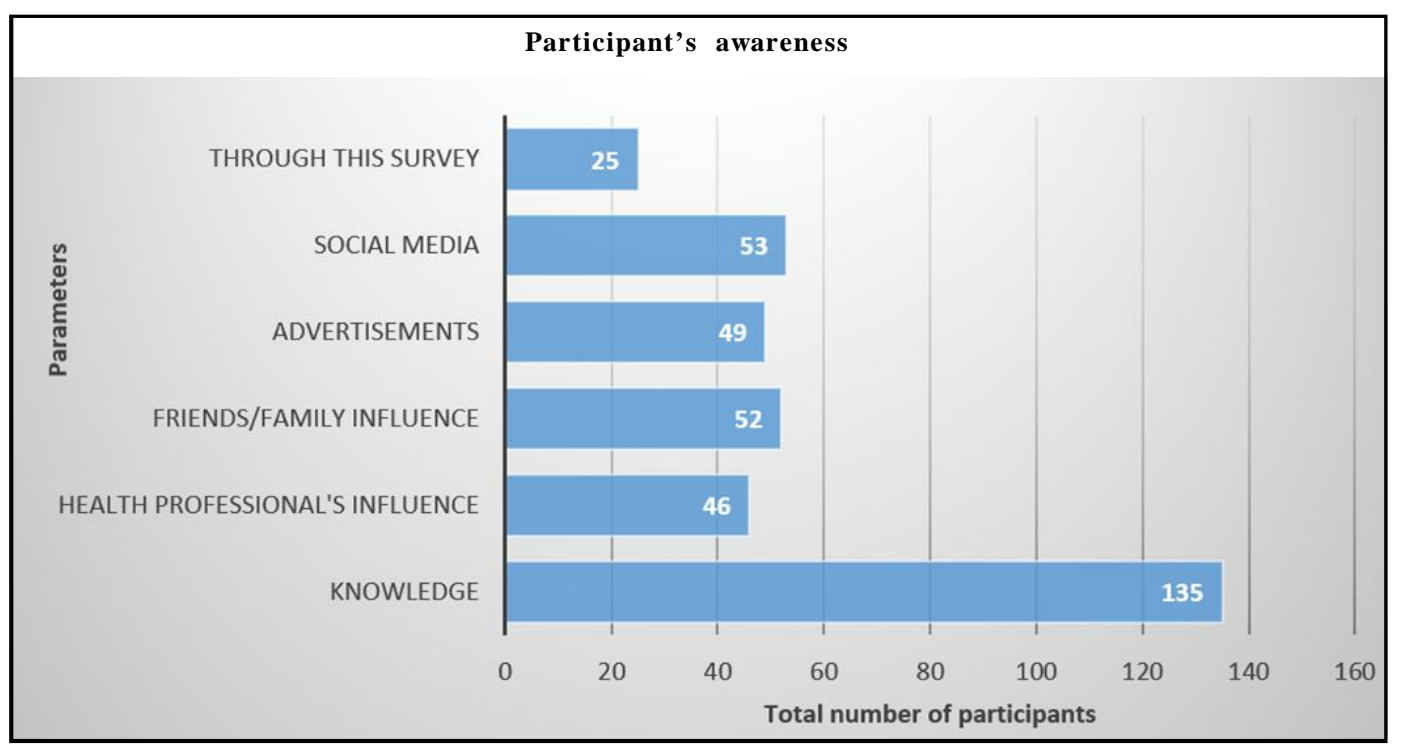

Figure 2: Participant's source of awareness about functional foods.

Participants as consumers gave priority to the nutrition of food items, followed by taste, price, and convenience (Figure 1). The majority of participants $47.8 \%$ (144) have the habit of checking the food label before buying the products while around $38.9 \%$ (117) sometimes check it, sometimes not and the rest $13.3 \%$ (40) do not check the label before buying the food item at all (Table 3 ). It was observed that $62.8 \%$ (189) of participants were aware of functional foods, but only $58.8 \%$ (177) of the total participants buy functional foods. This can be due to more awareness and knowledge of participants. Also, many factors affect the acceptable behavior of functional foods among consumers. 


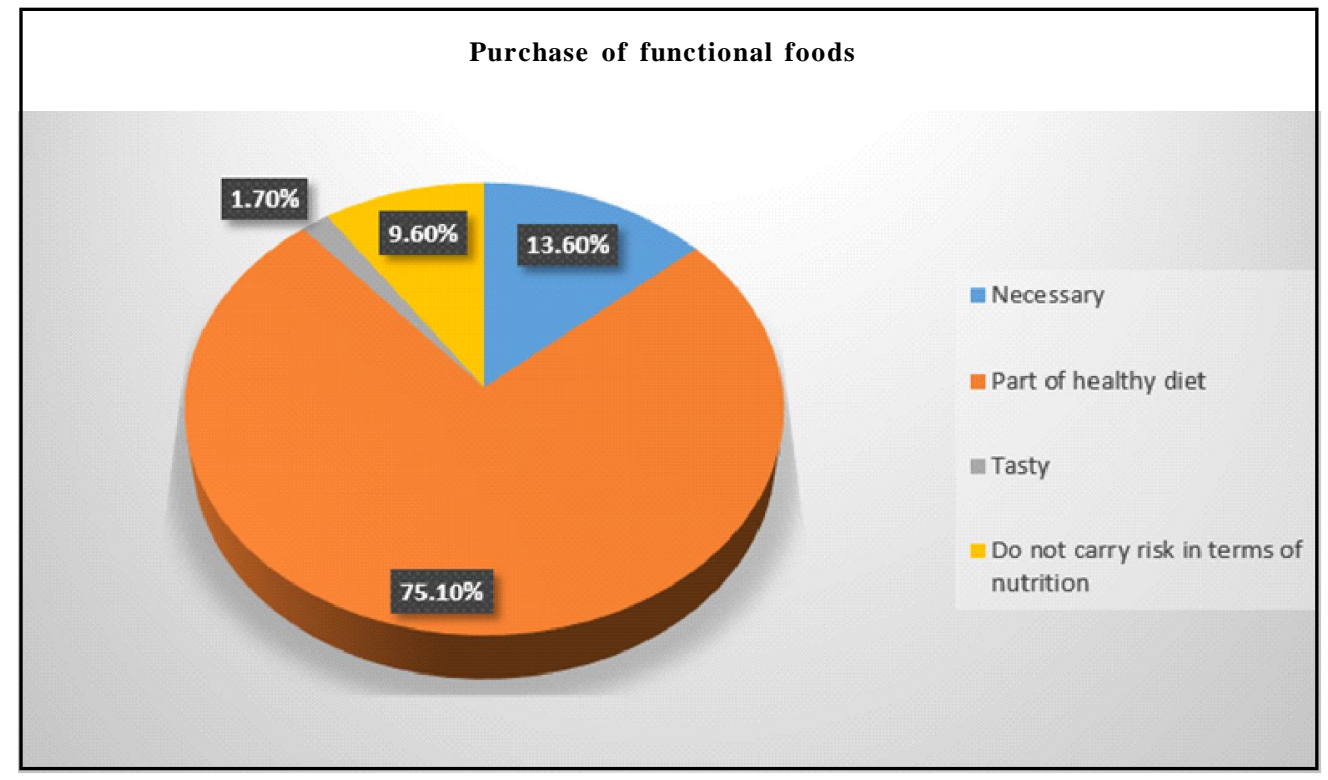

Figure 3: Reasons for purchase of functional foods by participants.

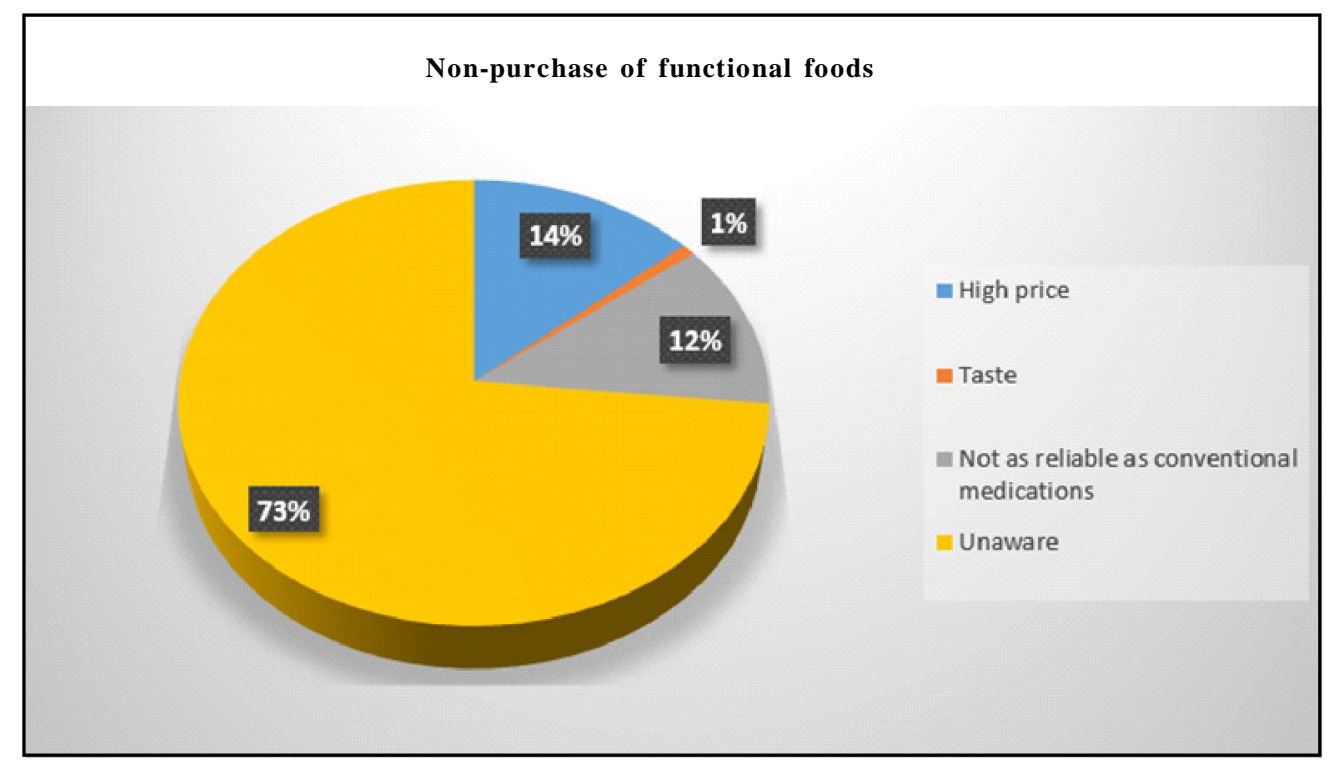

Figure 4: Factors influencing non-purchase of functional foods.

Yet around 37.2\% (112) of participants do not know about functional foods and $41.2 \%$ (124) of participants do not buy functional foods (Table 3). The majority of participants who consume functional foods knew functional foods. Most of them were made aware through health professionals, social groups, social media, and a few with the help of this survey (Figure 2). The majority of the functional food consumers purchase it because of its health benefits, i.e., $94.4 \%$ and a mere $5.6 \%$ because they are fond of the product. A vast majority of consumers believe functional foods to be part of a healthy diet. Some belief it to be necessary and not carrying risk in terms of health. Only a few consider it to be tasty. All these reasons for purchasing the functional foods by participants are depicted in Figure 3.
Out of 177 consumers, $35 \%$ believe in the health claims mentioned, and $56.5 \%$ do believe it sometimes as shown in Table 3. However only $31.6 \%$ of consumers were satisfied by the mentioned health claims, $63.3 \%$ of consumers could not figure out whether they are satisfied or not and the rest did not get the desired outcome. Out of the 177 consumers, $87 \%$ consume it to increase immune power, followed by $61.6 \%$ to reduce the risk of any heart disease, $51.4 \%$ to boost bowel health, $47.5 \%$ to reduce the risk of diabetes, and $29.4 \%$ to reduce the risk of disease like cancer. Thus, this can give evidence that the success of functional foods depends upon the taste, convenience, and impact it possesses on the health of the consumers (Verschuren et al., 2002). 


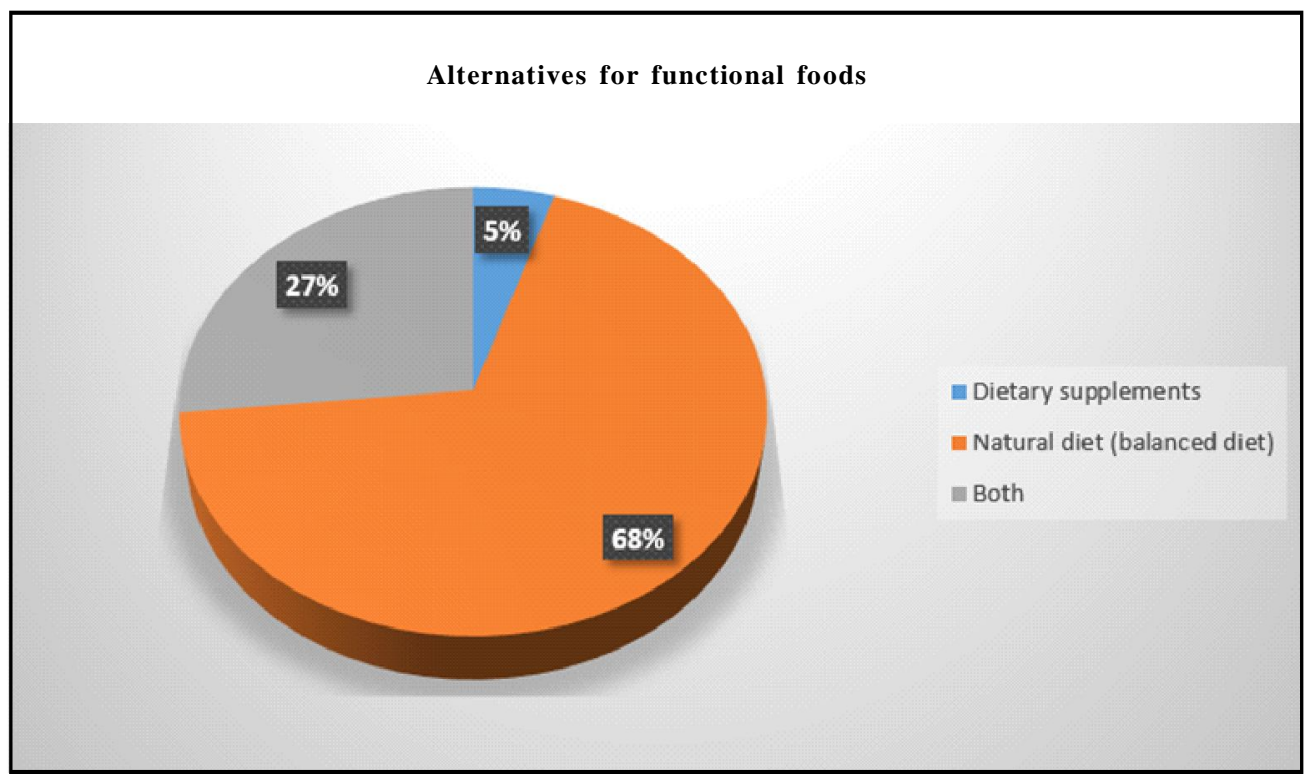

Figure 5: Participant's alternatives for functional foods.

Out of 124 participant's majority, $73.38 \%$ were unaware of such food products. Hence, they do not consume functional foods (Figure 4). A vast majority of non-consumers, i.e., $68.54 \%$ preferred taking a natural balanced diet instead of functional foods. A small proportion of $4.83 \%$ opted for dietary supplements as shown in Figure 5.

As it is shown in Table 3, consumers are more attracted to health claims and they are not giving preference even to the products of the companies having big name in the market, it proves that health claims and their appropriate presentation can critically impact the market structure of the whole product and it needs to be regulated. Table 3 also clearly showed that products with health claims carry a higher price in the market and become a beneficial factor for manufacturers and companies that can exploit this opportunity unethically and there again comes a need for it to be regulated. Most people are confused about health claims and they can not completely understand them. Not so, many peoples in India are aware of laws and regulations related to health claims more than $30 \%$ of them are completely unaware and more than $20 \%$ are uncertain. More than $95 \%$ of consumers support the idea of maintaining a list of authorized health claims and making it available for information to the general public. Consumers are finding some health claims hard to digest and it needs to be backed by scientific evidence and those scientific evidence needs to be displayed on packets of products in a fully easily understandable manner. Consumers want that there must be some online platforms or methods for judging the truthfulness of health claims.

\section{Discussion}

A survey study was also conducted in Belgium for 215 individuals in determining the acceptability of functional foods. Bivariate and multivariate analyses were conducted. The results revealed that according to bivariate analysis, women and older individuals showed more acceptability towards functional foods. Out of the total participants, $46.5 \%$ accepted the functional foods and this acceptability increased due to the presence of an ill member in the family (Verbeke et al., 2005).
One survey study was conducted among college students of Canada, the United States, and France for the acceptance of functional foods. The survey results obtained revealed that sex, country of origin, culture, health beliefs, and awareness affect the acceptability of functional foods among students. It was inferred from this survey that education awareness and labeling of the products help in increasing the acceptability of functional foods (Kolodinsky et al., 2008). The acceptance of functional foods in comparison with unhealthy food is important as the consumption of unhealthy food which comprises of usually increase fat and carbohydrate content, leads to the development of obesity and results in chronic and serious conditions of COVID-19 (Aday et al., 2020).

Different types of functional foods such as milk, dairy products, cereal products, beverages, and oils are consumed by a different number of participants as shown in Table 4 (Cakiroglu et al., 2018). A study conducted by Karelakis et al. (2019) also involved a survey regarding the consumer attitude in Greece towards consuming functional foods. According to this survey, consumers were conscious about their health and willing to pay more for functional foods that can help them in preventing the risk of infections and chronic diseases (Karelakis et al., 2019). As viral infections are responsible for an increasing number of chronic diseases and death worldwide including COVID-19 disease. Thus, functional foods are a safe and economical way to improve immunity to tackle viral infections (Alkhatib et al., 2020).

\section{Conclusion}

People think that the food they consume influences their body's physical and mental health. Hence, nowadays with the emergence of the pandemic COVID-19, people are very much inclined towards consuming new types of food and are open to trying new variants of the foods which would support their health. Hence, functional foods came to light. The functional foods industry is progressing worldwide. The outcome of our survey is vital to functional foods developers and marketers to contribute to fighting against COVID19 disease. According to our study, we found that people prefer functional foods to boost their immune system and thus back up 
their health. Adding to this result, young individuals and educated people (both female and male) consume these products for health benefits, especially during this pandemic situation, and to prevent the risk of chronic diseases. But, a lot of people still need to learn more about functional foods. Price, taste, and convenience are the three basic key driving factors for anyone to try and consume any new product. Therefore, the price needs to be lowered and production needs to be increased for it to reach everyone. People also need to be made aware of functional foods and the health claims provided to move forward towards a healthy future. Overall, the results provide valuable information regarding the needs and perceptions of nutrition and health information on functional foods and their consumption to stop spreading the COVID-19 disease by enhancing the immune system.

\section{Acknowledgements}

Dr. Rizwana, Dr. Eram Rao, Dr. Anita Sondhi and Dr. Aparna Agarwal conceived the study. Dr. Rizwana guided and assisted in the manuscript preparation. Anishka Verma, Krishan Kant and Deepak Kumar wrote the manuscript. All the authors approved the manuscript by final supervision.

\section{Conflict of interest}

The authors declare no conflicts of interest relevant to this article.

\section{References}

Aday, S. and Aday, M.S. (2020). Impact of COVID-19 on the food supply chain. Food Quality and Safety, 4(4):167-180.

Alkhatib, A. (2020). Antiviral functional foods and exercise lifestyle prevention of coronavirus. Nutrients, 12(9):1-16.

Ben Hassen, T.; EI Bilali, H. S. and Allahyari, M. (2020). Impact of COVID-19 on food behavior and consumption in Qatar. Sustainability, 12(17): $1-18$.

Bigliardi, B. and Galati, F. (2013). Innovation trends in the food industry: The case of functional foods. Trends in Food Science and Technology, 31(2): 118-129.

Çakiroðlu, F.P. and Uçar, A. (2018). Consumer attitudes towards purchasing functional products. Age, 18(25):494.

Haslberger, A.; Jacob, U.; Hippe, B. and Karlic, H. (2020). Mechanisms of selected functional foods against viral infections with a view on COVID-19: Mini review. Functional Foods in Health and Disease, 10(5):195-209.

Jain, S.; Sharma, K. and Khadke, M. (2014). Consumer behavior towards functional foods in India: A study of market drivers and challenges. IOSR Journal of Business and Management (IOSR-JBM), pp:33-40.
Jêdrusek Goliñska, A.; Górecka, D.; Buchowski, M.; Wieczorowska Tobis, K.; Gramza Micha3owska, A. and Szymandera Buszka, K. (2020). Recent progress in the use of functional foods for older adults: A narrative review. Comprehensive Reviews in Food Science and Food Safety, 19(2):835-856.

Karelakis, C.; Zevgitis, P.; Galanopoulos, K. and Mattas, K. (2020). Consumer trends and attitudes to functional foods. Journal of International Food and Agribusiness Marketing, 32(3):266-294.

Kaur, S. and Das, M. (2011). Functional foods: An overview. Food Science and Biotechnology, 20(4):861.

Kolodinsky, J.; Labrecque, J.; Doyon, M.; Reynolds, T.; Oble, F.; Bellavance, F. and Marquis, M. (2008). Sex and cultural differences in the acceptance of functional foods: A comparison of American, Canadian, and French college students. Journal of American College Health, 57(2): 143-149.

Kumar, S. and Krishnan, V. (2017). Phytochemistry and functional food: The needs of healthy life. J. Phytochem. Biochem, 1(1):1-3.

Küster-Boluda, I. and Vidal-Capilla, I. (2017). Consumer attitudes in the election of functional foods. Spanish Journal of MarketingESIC, 21:65-79.

Lobo, V.; Patil, A.; Phatak, A. and Chandra, N. (2010). Free radicals, antioxidants and functional foods: Impact on human health. Pharmacognosy Reviews, 4(8):118.

Marina, T.; Marija, C. and Ida, R. (2014). Functional foods and the young. Journal of Food Products Marketing, 20(5):441-451.

Martirosyan, D.M. and Singh, J. (2015). A new definition of functional food by FFC: what makes a new definition unique? Functional Foods in Health and Disease, 5(6):209-223.

Martirosyan, D. (2020). The emerging potential of functional foods in viral disease prevention. Bioactive Compounds in Health and Disease, 3(6): $95-99$.

Urala, N. and Lähteenmäki, L. (2007). Consumers' changing attitudes towards functional foods. Food Quality and Preference, 18(1):1-12.

Vella, M. N.; Stratton, L. M.; Sheeshka, J. and Duncan, A. M. (2014). Functional food awareness and perceptions in relation to information sources in older adults. Nutrition Journal, 13(1):1-12.

Verschuren, P.M. (2002). Functional foods: Scientific and global perspectives. British Journal of Nutrition, 88(S2):S126-S130.

Verbeke, W. (2005). Consumer acceptance of functional foods: Sociodemographic, cognitive and attitudinal determinants. Food Quality and Preference, 16(1):45-57.

World Health Organization. (2000). Obesity: Prevention and managing the global epidemic: Report of a WHO consultation. WHO Technical Report Series, 894. https://apps.who.int/iris/handle/ $10665 / 42330$ 